\title{
Pursuing National Security by Iran is Not Equal to Being Paranoid about the USA
}

\author{
Gerald Peter Mutonyi ${ }^{1}$ \\ ${ }^{1}$ Kenyatta University \\ P. 0. Box 43844-00100, Nairobi, Kenya
}

DOI: $10.22178 /$ pos. $68-6$

JEL Classification: K40

Received 26.02.2021

Accepted 28.03.2021

Published online 31.03.2021

Corresponding Author:

Gerald Peter Mutonyi

mutonyig@gmail.com

(C) 2021 The Author. This article is licensed under a Creative Commons Attribution 4.0 License @ (1)

\begin{abstract}
In most countries of the world where there is a strong western influence, there has been a persistent narrative that Iran is paranoid about the United States of America. It will not spare any grain to ensure the destruction of the mighty American nation. But according to the leaders of Iran, their actions are about the safeguarding of their country national security interest. Yet, there have been limited studies to respond to whether Iran is paranoid about the USA or if it is all about national security. Hence this study sought to illustrate the dangers of appeasing the USA when your national policies are in contract. The study selected a few countries and scenarios: Vietnam, Afghanistan, Iraq-Iran war, the Axil of Evil phrase, Iraq, and Syria for the illustration. The study has shown that the USA will not relent to pursue its national interest against those opposing it, notwithstanding the consequences on the recipients. This USA trend will continue to manifest to the unforeseeable, thereby putting Iran in danger that befell other nations who had opposed the USA. Based on the findings, the study concludes that Iran is not paranoid about the USA but is concerned with preserving its national security and interests.
\end{abstract}

Keywords: national security; paranoid; sanctions; terrorism; war.

\section{INTRODUCTION}

National security revolves around the neorealism ideals, according to which worldwide policies are mostly a struggle between states to acquire power under conditions of anarchy, as they contest for their national interests. In this environment, states are dependent on their military supremacy to assure those interests, countering the threats arising from other states [21]. This way, national security is protected by distributing the balance of power and national sovereignty between the different States. This traditional National Security ideal is the sustained capability of a country to pursue the advancement of its inner being without severe interference, or threat of interference, from foreign powers [24]. Therefore, national security has to be a state's ability to maintain its sovereignty and independence, assuring its people and protecting their properties.

According to Gleeson, paranoia describes a "destructive-obstructive" personality that makes others feel uneasy, and whom themselves feel under threat and who does not perceive events at face value but instead is mistrustful of others and their motives and making wildly untrue allegations [18]. Consequently, this kind of paranoia state is likely to be dangerous and violent. Therefore, this study will be relating to whether Iran has these "destructive-obstructive" personality towards the USA or not.

Sanctions have remained a significant element of USA policy on Iran ever since Iran's 1979 Islamic Revolution that toppled the Shah of Iran, Mohammad Reza Pahlavi, a critical American ally. The USA first enforced sanctions on Iran on 14th November 1979, freezing Iranian state assets in America in reaction to Iran's confiscation of the USA embassy and US diplomats in Tehran. In the following decades of the 1980s and 1990s, USA sanctions on Iraq were meant to attempt to coerce Iran to desist from being supportive of terrorism acts and minimise Iran's strategic influence in the Middle East [11]. 
But strangely enough, during the 1980-88 IranIraq hostilities, the USA state often insisted that it was neutral in the war. However, the Reagan administration in January 1981 discretely permitted Israelis, bitter foes of Saddam Hussein, to provide numerous billion dollars' worth of USA produced arms and spare parts to Iran [33].

During the 2014-17 "Operation Inherent Resolve", when the USA and its allies were fighting the Islamic militant ISIS, it is significant to remember that Iran played a crucial role in the fight. The Iranian army and its backed militias pushed ISIS back in Iraq and Syria [34]. The warfare was coordinated surgically without any incidents of friendly fire from the sworn enemies. This notwithstanding that Iran was under sanctions from the side, it gave a boost to this showcased the geopolitical power and influence extend of influence that the Shia powerhouse Tehran held in the Middle East region.

After the mid-2000s, the USA and some international nations concentrated mainly on convincing Iran to approve to abandon its nuclear ambition. Hence, President Obama indicated that the USA allies in the Persian Gulf and Iran require to discover a practical way to share the neighbourhood and introduce some cold peace [36]. The Obama Administration in 2015 waived appropriate sanctions and annulled some executive orders (EOs). The remaining American sanctions were: USA trading with Iran, Iran's support for regional armed factions, Iran's human rights abuses, Iran's determinations to obtain missile and more developed conventional arms expertise [14]. The USA, European Union (EU) and other nations sought to retain the economic gains of the JCPOA, benefitting Iran to persuade Iran to remain in the nuclear accord and reduce her pursuit for the middle East domination. And Iran was baited to accept the 2015 multilateral nuclear accord due to the broad sanctions relief the arrangement brought.

The Trump administration decided to discard the agreements made between the USA, its allies and Iran. It re-imposed by going beyond economic bounds, and included Iran's foreign minister Mohammad Javad Zarif in its sanctions program, and labelled the Islamic Revolutionary Guard Corps (IRGC) as a terrorist group [39]. As all these transpired, Tehran continued in complete compliance with the JCPOA for an entire year after the USA had withdrawn from the accord [11; 39]. The EU and other nations had strived to keep the economic gains of the JCPOA going to Iran to encourage Tehran to continue with the nuclear accord. But Tehran withdrew and continued to develop its missile armament while declining to restart dialogues with the USA on a reviewed JCPOA.

From the overview above, this relationship between Iran and the USA has undermined sanctions as a diplomatic means, strengthening the beliefs of those in Tehran who certainly did not have faith in the commitment. And it has inspired the Iranian hardliners towards other aggressive Iranian national security policies. Notwithstanding, there have also been incidents in the global politics and relations involving the USA that would keep any leader or most nations wary. The supreme leader Ayatollah Khomeini must have learned from them over the years. Consequently, this paper sets out to discuss the incidents to Iran and the USA over the years to confirm whether Iran is paranoid of the USA or whether its national security guides it.

\section{RESULTS AND DISCUSSION}

\section{The Vietnam Lesson}

The Vietnam War was a civil war between the pro-Western South and the communist North. Other countries, including the United States, intervened, bolstering both sides, especially South Vietnam, with troops and armaments [38]. The practical American participation in the war commenced in 1954, although the continuing skirmish in the region had spread backwards for several decades. It followed the Japanese defeat in World War II in 1945, and Japan withdrew its military from Vietnam, conceding for the Frencheducated Emperor Bao Dai to be in charge [17]. Looking to recapture the territory's charge, the French supported Bao Dai and set up Vietnam's nation in July 1949, with Saigon as the capital.

Ho's Viet Minh forces saw a chance to grasp command and instantly rose and took over Hanoi's city and proclaimed the Democratic Republic of Vietnam, with Ho as the president. But while the Soviets and Chinese supported Ho and his supporters to model their nation under communism, Bao and many others supported a close economic and cultural Vietnamese tie to the capitalist [27]. The armed war between Ho's communist military in the North and Bo's capitalist 
army in the South was decided by Viet Minh's triumph in the Battle of Dien Bien Phu in May 1954. At a Geneva conference in July 1954, a treaty was signed that split Vietnam along the latitude known as the 17th Parallel (17 degrees north latitude), with Bao in control of the South and Ho in control in the North [32]. But both parties were seeking the same objective of a unified Vietnam.

As the Cold War heightened globally, the USA toughened its policies against the Soviet Union allies. In 1955, President Eisenhower guaranteed his support to Diem, the strongly anti-communist politician who had pushed Emperor Bao aside and South Vietnam. With guidance and materials from the USA armed forces and the CIA, Diem's military force hunted down those who sympathised for Viet Minh, arresting thousands of people, and many were viciously tortured and executed [3]. The USA has permanently hardened its policies on whoever is not their ally, especially those who topple their allies. Ever since Iran's 1979 Islamic Revolution that toppled the Shah of Iran, Mohammad Reza Pahlavi, a critical American ally, it has always been a matter of when and not if. The supreme leader of Iran, Ayatollah Khomeini and his administration will therefore not be waiting for a possibility of thousands of arrests, and many of whom will be brutally tortured and executed, as was the case in Vietnam. Instead, the leaders in Tehran will be engaged in bolstering their national defences, not excluding the pursuance of weapons of mass destruction.

During the 1957-60 period, Diem's many opponents, both communist and non-communist within South Vietnam, established resistance to his repressive regime. Washington thought that Hanoi was supporting it. Under the "domino theory," which Washington held that, if any Southeast Asian nation leaned to communism, several others might follow, the USA committed a military intervention [8]. But by 1962, the US military presence in South Vietnam had reached some 9,000 troops, compared with fewer than 800 during the 1950s [20]. The continued Iranian influence in the Persian Gulf might lead to the "domino effect" as other Middle East players fall to Iranianism, for example, the Houthis who are Zaydi Shiites, or the Zaydiyyah in Yemen, and the Hezbollah, the Shiite movement in Lebanon who became a role model and mentored for the Houthis. Therefore, this predisposes Iran to the USA, committing a large scale military intrusion to curtail it.
The intrusion might also predispose Iran to the 'Westmoreland policy' of attrition. The American-South Vietnamese battle in the South was battled predominantly on land, mainly under General William Westmoreland's leadership, in collaboration with General Nguyen Thieu's regime, pursued a policy aimed at killing as many enemy soldiers as probable rather than striving to capture territories [12]. As a rational leader, Ayatollah Khomeini knows that they have a responsibility to protect their people and territory against what their enemy is known to be capable of undertaking. Therefore, Tehran bolsters its defences in what the western media refers to as aggressive measures.

After years of war, approximately 2 million Vietnamese died, whereas 3 million were injured, and an additional 12 million became refugees [6]. The war had entirely devastated the nation's infrastructure. The devastation of war is what most sensible leaders would pursue to prevent. They would achieve the same through deterrence and the mutual assurance of destruction of the enemy. For that reason, the pursuance of weapons of mass destruction and other clandestine manoeuvres are ways by which Tehran pursues to preserve its million people and the nation's infrastructure against the USA.

\section{The Afghanistan Lesson}

A USA and allied armed forces coalition intruded into Afghanistan weeks after the 11th September 2001 coordinated strikes in the United States. The military campaign was against Al Qaeda and punished and ousted the Taliban government for harbouring and supporting Al-Qaeda leaders who were the mastermind [11]. The ultimate objective of USA determinations in Afghanistan was to ensure that the country is never used as a hub for planning and preparing attacks against the USA. But the incursion has left the country on the verge of irreparable destruction, which serves as a lesson to Ayatollah Khomeini.

Following the departure of the Soviet military in 1989 , the nation descended into civil war as the Mujahedeen leaders turned on each other. The Afghans and the rest of the world, exhausted from persistent conflict, began to look to the Taliban to restore order and security and create national reconciliation quickly. The Taliban enforced progressively stricter laws grounded in conservative understandings of Islam. Despite 
the Taliban justice being bloody due to the imposition of Sharia law enforced by the Taliban Religious Police, Afghans were moderately safeguarded from the physical insecurities of conflicts [16]. The Afghans' security was safeguarded on the frontiers of Severe Insecurity, Weakened Public Health System, Inaccessible Education, Climate-induced vulnerability and Forced Displacement until the Taliban government was uprooted and replaced by the leaders who could not reconcile the whole country.

According to the Advanced Training Program on Humanitarian Action, the civilian population in Afghanistan have been drawn in cycles of violence and destruction that have considerably distorted the nation's economic, political and social structures [2]. Economic growth is crucial to Afghanistan's long-term firmness, although there are mixed future development pointers. Years of conflict have inhibited the growth of most internal manufacturing establishments, including mining [11]. Nonetheless, Afghanistan's economic and political future still looks unclear, and in so way negative, due to continuing conflicts.

The nation's security condition is more unstable and delicate currently than at the beginning of the USA incursion [30]. It has been estimated that complex suicide attacks are the primary source of civilian fatalities, mostly in urban regions.1 These assaults are allegedly targeting the state and the USA and allies, but they instead result in many civilian casualties. Therefore, the citizens residing in town and cities are exposed to a recurrent upsurge in violence that interferes with their access to livelihoods services. The enduring targeting of civilians and the infrastructure has resulted in prevalent susceptibilities for people. This aspect has been widespread in the health sector due to intentional targeting of health amenities hence weakening an already weak health sector [1].

Currently, Afghanistan is among the countries with the lowest literacy rates for the ages above 15 . The literacy rate of men at $62 \%$ and women at $18 \%$ (the median for developing countries is $70 \%$ for males and $57 \%$ for females) [2]. Estimates had indicated that, by the end of 2017,

\footnotetext{
${ }^{1}$ United Nations. (2018). The situation in Afghanistan and its implications for international peace and security. Retrieved from

https://unama.unmissions.org/sites/default/files/sg_repor t_on_afghanistan_6_june.pdf
}

around 507,000 Afghans were to be forced to run away from their homes as a result of war over the year [10]. The war-affected zones have stimulated most people to flee to urban areas, where possibilities of livelihoods and access to services are much higher.

Since 2009, there had been a general certainty amongst the commentators that Afghanistan was headed towards disorder and that the USA and its allies lacked appropriate counterinsurgency (COIN) strategy [3]. From security to health, the citizens of Afghanistan are afflicted at every single angle of their lives. Up to date, the USA and its allies have not been able to conceive a COIN approach. Consequently, the country broke down, and it has never stabilised. This serves as a good lesson for Tehran's leadership, who realised that a weakened military force would be a temptation for the USA and its allies to invade the country and never get to fix it. Therefore, in its pursuit of avoiding going the Afghanistan route, Iran has been labelled a rogue nation that is allegedly obsessed with the USA's destruction.

\section{The Iran-Iraq War Lesson}

During the 1980-88 Iran-Iraq war, the USA government often insisted that it remained neutral. However, the Reagan government discretely resolved moments after taking office in January 1981 to permit Israelis, bitter foes of Saddam Hussein, to supply numerous billion dollars' worth of USA manufactured weapons and spare parts to Iran [33]. That intervention and the resolve to assist Tehran aided it in disregarding initial expectations of a rapid Iraqi triumph and attaining significant achievements early in the conflict, which had commenced with an Iraqi assault in September 1980.

In 1982, the Reagan Administration secretly resolved to hand over highly classified information to President Saddam Hussein. They also authorised the USA-made war weapons to assist Iraq in forestalling an impending loss in Iran's conflict. The USA decision to supply pivotal help to Baghdad was reached after the USA intelligence organisations cautioned that Baghdad was on the brink of actually being overrun by Tehran, whose military had been reinforced the year earlier by clandestine cargoes of the USA-made weapons [33].

The Americans were supplying both parties to ensure that neither party domineers the strategic 
oil region. And it resulted in enormous loss of human lives, billions of dollars of expenses and depleted infrastructures for both the feuding nations. When nations are not distinctively militarily strong, they are vulnerable to manipulation by the USA for its benefits, for instance, ensuring its uninterrupted oil supplies. That is a lesson that Tehran learned, and it has been trying to rectify it so that, now and in future, it will not be manipulated to engage in a non-decisive war where it is relying on a discreet external supply of weapons.

On Thursday, 20th September 2001, President Bush of the United States of America, while addressing a joint session of Congress and the nation, drew a red line by telling the world that, "Either you are with us or you are with the terrorists". The assumption was that the division between Us and Them had been equated with the division between Good and Evil. Consequently, in such a dualistic impression of the world, the USA represents Good and that anything it chooses to undertake is Good. In contrast, all others that offend or inconveniences it are Evil [19].

In less than five months after the 11th September 2001 Al-Qaeda attacks in Washington and New York, President Bush, in the 2002 State of the Union Address, made a proclamation referring to three nations: Iraq, Iran and North Korea, as "axis of evil". According to Bush, these three rogue nations financed, harboured and aided terrorists and subsequently threatened the world's peace. Hence, this idiom of "axis of evil" characterised a hallmark of Bush's government foreign policy, even though none of the attackers was citizens of the three nations [37].

Granting Iran membership in the 'Axis of Evil' was probably first, the usage of the phrase Axis of Evil was a redefining of the American "War on Terror," as it shifted focus from Osama bin Laden and Al-Qaeda together with their allies and bases, whose association ranged from minimal to nonexistent [19]. The Shiite cleric's general hostility to the United States (opposition to Good must necessarily be Evil) that Tehran does not recognise the Palestinians' struggle against the Israelis as constituting terrorism, and explicitly it's backing of Hezbollah. After Shiite clerics gripped authority during the 1979 revolution, Iran became a wealthy nation supporter of 'terrorism' in its ability [9].

Second, it also shifted focus on those possessing chemical and biological weapons because they could sell or give them to terrorists to attack
Americans. Ironically, those already possessing nuclear weapons are immune from an imminent American attack, for instance, Pakistan, whose military intelligence service was the main backer of the Taliban, and perhaps North Korea [19]. Hence the focus is primarily on the states possessing chemical and biological weapons and may, in the future, acquire nuclear weapons. They may, in the future, perhaps be tempted to give or sell to terrorists. Under these criteria, Iran qualifies that it is considered a rogue state, has chemical and biological weapons and strives to achieve a nuclear program.

Third, the division between Us and Them had been equated with the division between good and Evil. Consequently, in such a dualistic impression of the world, the USA represents the enforcer of Good and that anything it chooses to undertake is Good. In contrast, all others that offend or inconveniences it are Evil [19]. Because Iran is pursuing its divergent aspirations and philosophies, it is an evil that must be overcome.

\section{The Iraq Lesson}

In approximately five months after the 11th September 2001 coordinated attacks on Washington and New York, President Bush in 2002 proclaimed referring to three states: Iraq, Iran and North Korea, as "axis of evil". The phrase "axis of evil" consequently was confined to perceived hostile countries that may, at some time in the future, attain nuclear weapons which they may, at some time in the future, perhaps be tempted to offer to terrorists [19].

By mid-September 2002, officials in the USA and her allies had impressed their leadership that Iraq was in pursuance of weapons of mass destruction. It was alleged that there was evidence of Iraqi development of ballistic missiles during that time, its ability to produce biological weapons in a mobile laboratory and of chemical capabilities [4]. If the USA were going to change Iraq's establishment, it would create a new blueprint of democracy in the Middle East [15]. Iran most definitely qualified under these criteria in that it has a nuclear program, and its rhetoric and actions have never proved that it will not offer out these weapons. The same can be said of Iraq.

The Iraq war, sometimes known as the "Iraqi Freedom Operation", began on 20th March 2003, with the USA and its allies' incursion into Iraq. The War in Iraq brought to reality what a super- 
power in a region can and cannot achieve. The world watched as a regional superpower was gradually weakened in its self-image and before the world. The National Intelligence Estimate of January 2007 on Iraq published a blatant depiction of a polarised and violent state overwhelmed by acts of terror, an insurgency, a widespread unorganised and organised criminality, a civil war and a failed state [31]. Whether an individual approves of America's assault on Iraq, it is evident that its mismanagement has borne a civil war that has left any little military or political alternatives.

The current American administration emphasises that Iran has the burden to prove that it is not pursuing after acquiring nuclear weapons and that neither the USA nor the UN needs to prove that Tehran does not have those ambitions. This is precisely the situation Saddam Hussein found himself before the trumpets of war sounded that left Iraq in turmoil. And subsequently, it was alleged that any evidence presented was fake [19]. It should be remembered that every measure the UN ever took against Baghdad with the inclusion of the cease-fire after the Gulf war, the inspections regime, and sanctions had been binding on every member of the world body as a matter of international law [23]. Did Tehran learn any lesson from the history of America dealing with Saddam Hussein? The leaders in Tehran must have caught a lesson or several, and the lessons are currently informing their relation and handling of the USA.

\section{The Syrian Lesson}

State of the Union speech by Bush in 2002 listed Iran and Iraq, and North Korea as part of Evil's axis. During that year, John Bolton, the then under-secretary of state, included Syria to the list [7]. The USA also declared Syria as a target for regime change [29]. The fear that the USA and its allies would switch their focus to topple their governments after they were finished with Iraq pushed the Syrians and Iranians to increase security collaboration with one another. They also began supporting diverse insurgent blocs in Iraq to preoccupy the USA military not to be attacked [35].

Fast forward, on 17th December 2010, Al-Tayeb Bouazizi, a Tunisian vegetable retailer, set himself ablaze outside a government building to protest against corruption. Bouazizi's self- immolation catalysed uprisings in the months that followed, first in Tunisia and then in Bahrain, Egypt, Iraq, Libya, Syria, and Yemen in what is popularly known as the Arab uprising [35]. As Syria slide into civil conflict in the coming years, the CIA began to train and arm some Syrian rebels [22] secretly. Although Washington coordinated to support specific rebel forces in the Syrian civil war, they were fighting ISIS and at the same time waging war on Assad in Syria, even when ISIS was battling Bashar al-Assad [28]. Therefore, they battled ISIS to weaken them from battling with Syria, whereas Syria was battling the USA supported allies. This may sound insane, but it is insane for the reason that it is outrageous. But the same is not outrageous for the American policymakers who were being informed by their own 'national security. That national security they were pursuing had already blared to Tehran leadership that, when the USA and the allies are finished with Syria, they will get involved in Iran.

Consequently, Iran will be expected to bolster its economic, political, cultural, religious, and military values in anticipation of a direct attack or proxy attacks from the USA and its allies. Tehran has been sending special forces, agents, weapons, and nonmilitary support to Damascus. And the Iran-supported Lebanese Hezbollah had dispatched advisers and then military units to help Al-Assad clump on the uprising [25; 40]. And in case of a protracted stalemate in the civil war, then Syria might perish a slow death, as the rebels control some areas and others held by the government [26]. The rebels sponsored by the USA and its allies are as tough to beat as a nationstate.

Food security in Syria is seriously destabilised due to infrastructure damage and massive population displacement, which has left more than half of the population living in poverty [5]. Due to the current stalemate in the war, the situation in Syria is desperate. Just to quote David Lesch, professor of history at Trinity University in San Antonio, Texas.

"Putrid piles of garbage lie on streets because basic services have ceased operating. Running water and electricity are either unavailable - by design, as a form of collective punishment, or due to disruption - or else are available only sporadically. Storefronts are shuttered, battered and broken. The stores themselves are empty of both people and products, as either the retailers have 
deliberately removed the stock, storing it for a safer day, or else - more likely - vandals have pilfered the goods on one or either side of the conflict. Shells and bullets pockmark the walls of buildings. Many streets are deserted, littered with debris and marked with the occasional bloodstain" [26].

Civil warfare continues to impact Syria, which is currently a playground for both the state and non-state actors. The Syrian conflict is no longer a clear situation of one party battling the other. Consequently, Iran is not paranoid but is informed by its need for self-preservation, not desiring to go the Syrian way.

\section{CONCLUSION}

The dualistic East-West division disappeared and was substituted by a divide between states committed to the USA and the "rogue nations" with divergent aspirations and philosophies. North Korea, Iran, Iraq, China, Syria, Russia and Sudan were in the latter camp. Each one had possession or aspired to possess 'weapons of mass destruction, and they were labelled as sponsors of terrorism. Consequently, defending and deterring against rogue nations has historically been a national security objective of the USA and its allies. Since the end of World War Two, the USA has been embroiled in civil wars, revolutions, and political uprisings in nonaligned and third world countries on the pretext that it has strategic, economic, and ideological interests the regions [8].

In the current neo-realism world, Iran cannot trust the USA, as shown from the discussion and must always be prepared to gear up for conflict. Iran can only act to serve moral purposes when its security interests are not being threatened. Its scepticism should be filled the USA and allies producing more "just and humane policies". There is no nation on earth desiring to be burdened or yearning for enslavement as it peacefully looks forward to the night bombs and invasions into its territory. Consequently, Iran is not paranoid of the USA but is concerned that its national security and national interests are being threatened.

\section{REFERENCES}

1. Acerra, J. R., Iskyan, K., Qureshi, Z. A., \& Sharma, R. K. (2009). Rebuilding the health care system in Afghanistan: an overview of primary care and emergency services. International Journal of Emergency Medicine, 2(2), 77-82. doi: 10.1007/s12245-009-0106-y

2. Tronc, E., \& Nahikian, A. (2018). Fragile Future: The Human Cost of Conflict in Afghanistan. SSRN Electronic Journal. doi: 10.2139/ssrn.3291982

3. Ahern, T. (2009). CIA and the Generals. Retrieved from https://nsarchive2.gwu.edu/NSAEBB/NSAEBB284/1-CIA_AND_THE_GENERALS.pdf

4. Alibek, K. (2003, March). War in Iraq: Weapons of Mass Destruction. Retrieved from https://www.washingtonpost.com/wpsrv/liveonline/03/special/world/sp_iraq_alibek033103.htm

5. Alkaff, S. (2014). Syria. Counter Terrorist Trends and Analyses, 6(1), 32-33. Retrieved from www.jstor.org/stable/26351220

6. Barnett, A., Stanley, T., \& Shore, M. (1992). America's Vietnam Casualties: Victims of a Class War? Operations Research, 40(5), 856-866. Retrieved from http://www.jstor.org/stable/171812

7. Bolton. J. (2002). Beyond the Axis of Evil: Additional Threats from Weapons of Mass Destruction. Washington: Heritage Foundation.

8. Butterly. L. (2008). Rhetoric and Reality - A History of the Formation of the 'Domino Theory. Retrieved from http://ulsites.ul.ie/historystudies/sites/default/files/historystudies_13_butterly_rhetoric.pdf

9. Byman, D. (2020). Understanding, and Misunderstanding, State Sponsorship of Terrorism. Studies in Conflict \& Terrorism, 1-19. doi: 10.1080/1057610x.2020.1738682 
10. Common Humanitarian Fund. (2017). Afghanistan. 2017 Annual Report. Retrieved from https://www.humanitarianresponse.info/sites/www.humanitarianresponse.info/files/docume nts/files/afghanistan_chf_-_annual_report_2017.pdf

11. Congressional Research Service. (2021, April 6). Iran Sanctions. Retrieved from https://fas.org/sgp/crs/mideast/RS20871.pdf

12. Daddis, G. (2014). Westmoreland's War: Reassessing American Strategy in Vietnam. New York: Oxford University Press.

13. Fair, C. (2010). Clear, Hold, Transfer: Can Obama's Afghan Strategy Work? Asian Affairs, 37(3), 113131. Retrieved from http://www.jstor.org/stable/44173590

14. Fayazmanesh, S. (2003). The Politics of the U.S. Economic Sanctions Against Iran. Review of Radical Political Economics, 35(3), 221-240. doi: 10.1177/0486613403254535

15. Gompert, D., Binnendijk, H., \& Lin, B. (2014). Blinders, Blunders, and Wars. Santa Monica: RAND Corporation

16. Goodson, L. (2015). Afghanistan's Endless War: State Failure, Regional Politics and the Rise of the Taliban. N. d.: Vancouver University of Washington Press.

17. Goscha, C. (2011). Historical Dictionary of the Indochina War (1945-1954). Copenhagen: NIAS Press.

18. Harper, D. (2002). The Politics of Paranoia: paranoid positioning and conspiratorial narratives in the surveillance society. Surveillance \& Society, 5(1). doi: 10.24908/ss.v5i1.3437

19. Heradstveit, D., \& Bonham, G. (2007). What the Axis of Evil Metaphor Did to Iran. Middle East Journal, 61(3), 421-440. Retrieved from http://www.jstor.org/stable/4330418

20. History.com (2020, February 28). Vietnam War. Retrieved from https://www.history.com/topics/vietnam-war/vietnam-war-history

21. Jehangir, H. (2012, February 19). Realism, Liberalism and the Possibilities of Peace. Retrieved from https://www.e-ir.info/2012/02/19/realism-liberalism-and-the-possibilities-of-peace

22. Ford, J. (2009). Beyond the 'War on Terror': A Study of Criminal Justice Responses to Terrorism in the Maghreb. Retrieved from https://www.africaportal.org/publications/beyond-the-war-onterror-a-study-of-criminal-justice-responses-to-terrorism-in-the-maghreb/

23. Karsh, E. (2002). Saddam and the Palestinians. Retrieved from https://www.researchgate.net/publication/314231485_Saddam_and_the_Palestinians

24. Kennan, G. (1949, April 30). The Inauguration of Organized Political Warfare. Retrieved from https://digitalarchive.wilsoncenter.org/document/114320

25. Kilcullen, D. (2016). Blood Year: The Unraveling of Western Counterterrorism. New York: Oxford University Press.

26. Lesch, D. (2012). Whither Syria? In Syria (pp. 206-241). Yale University Press. Retrieved April 11, 2021, from http://www.jstor.org/stable/j.ctt32bg42.13

27. Martignago, M. D. (2018). Vietnamese Farmers That Changed the World: The Impact of the Vietnam War on the Cold War. The General: Brock University Undergraduate Journal of History, 3, 163190. doi: 10.26522/gbuujh.v3i0.1691

28. Mutonyi, G. P. (2020). From Old Wars, To New Wars. Path of Science, 6(6), 9001-9011. doi: $10.22178 /$ pos.59-10

29. Neumann. P (2014). Suspects into Collaborators. London Review of Books, 36(7). Retrieved from https://www.lrb.co.uk/the-paper/v36/n07/peter-neumann/suspects-into-collaborators

30. Norland, R. (2018, September 21). The Death Toll for Afghan Forces is Secret. Here's Why. The New York Times. Retrieved from https://www.nytimes.com/2018/09/21/world/asia/afghanistansecurity-casualties-taliban.html 
31. Pascual, C., \& Pollack, K. (2007). Salvaging the Possible: Policy Options in Iraq. Retrieved from https://www.brookings.edu/wp-content/uploads/2016/06/pascual_pollack200709.pdf

32. Pitts, R. (1956). The "logic" of the seventeenth Parallel as a boundary in Indochina. Yearbook of the Association of Pacific Coast Geographers, 18, 42-56. doi: 10.1353/pcg.1956.0005

33. Hersh, S. M. (1992). US Secretly Gave Aid to Iraq Early in Its War Against Iran. The New York Times. Retrieved from https://www.nytimes.com/1992/01/26/world/us-secretly-gave-aid-to-iraqearly-in-its-war-against-iran.html

34. Shane, S., \& Venkataraman, S. (2000). The Promise of Enterpreneurship as a Field of Research. The Academy of Management Review, 25(1), 217. doi: 10.2307/259271

35. Tankel, S. (2018). With Us and Against Us: How America's Partners Help and Hinder the War on Terror. New York: Columbia University Press.

36. Goldberg, J. (2016, April). The Obama Doctrine. Retrieved from https://www.theatlantic.com/magazine/archive/2016/04/the-obama-doctrine/471525/

37. The Washington Post. (2002, January 29). Text of President Bush's 2002 State of the Union Address. Retrieved from https://www.washingtonpost.com/wpsrv/onpolitics/transcripts/sou012902.htm

38. Tiwari, S. C. (1968). US Involvement in Vietnam. International Studies, 10(1-2), 35-47. doi: $10.1177 / 002088176801000103$

39. Vogt, A., \& Jalilvand, D. (2019). One Year After the Re-Imposition of Sanctions. Retrieved from http://library.fes.de/pdf-files/iez/15761.pdf

40. Trofimov, Y. (2015, April 29). New Saudi Monarch Brings Major Change at Home. Wall Street Journal. Retrieved from https://www.wsj.com/articles/new-saudi-king-brings-major-change-athome-and-abroad-1430310152 